\title{
A national checklist of marine Mollusca in Spanish waters
}

\author{
Serge Gofas ${ }^{1}$, Ángel A. Luque ${ }^{2}$, José Templado ${ }^{3}$, Carmen Salas ${ }^{1}$ \\ ${ }^{1}$ Departamento de Biología Animal, Universidad de Málaga, E-29071 Málaga, Spain. \\ (SG) (Corresponding author) E-mail: sgofas@uma.es. ORCID iD: http://orcid.org/0000-0002-3141-3700 \\ (CS) E-mail: casanova@uma.es. ORCID iD: http://orcid.org/0000-0002-7372-1939 \\ ${ }^{2}$ Laboratorio de Biología Marina, Departamento de Biología, Universidad Autónoma, C/Darwin 2, E-28049 Madrid, Spain. \\ (AAL) E-mail: angel.luque@uam.es. ORCID iD: http://orcid.org/0000-0001-7890-5537 \\ ${ }^{3}$ Museo Nacional de Ciencias Naturales, CSIC, José Gutiérrez Abascal 2, E-28006 Madrid, Spain. \\ (JT) E-mail: templado@mncn.csic.es. ORCID iD: http://orcid.org/0000-0002-6571-4720
}

\begin{abstract}
Summary: A checklist of marine Mollusca recorded in Spanish jurisdictional waters is presented, based on a thorough literature search and a limited input of recent field work. The list is detailed according to the five demarcations of the Marine Strategy Framework Directive (NOR, Spanish north coast; SUR, Spanish coast of the Gulf of Cádiz; ESAL, Strait of Gibraltar and Alboran Sea; LEBA, East coast of Spain and Balearic Islands; CAN, the Canary Islands). The list differentiates coastal species living from the supralittoral zone to the shelf break, deep-sea benthic or demersal species, and holoplanktonic species, and also distinguishes between non-indigenous species and species endemic to a particular demarcation. A total of 2466 marine Mollusca species have been reported from Spanish waters, of which 1126 are recorded only from waters surrounding the Iberian Peninsula, 498 are recorded from the Canaries only, and 842 are shared. That total number represents around $5.5 \%$ of the global marine molluscan richness. Shore and shelf species are the most numerous (1837), followed by deep-sea benthic species (490) and pelagic species (139), but the contribution of the deep-sea species is most noteworthy in NOR. All eight molluscan classes were represented, but solenogastres and scaphopods were notably more represented than usual in NOR. Species richness in SUR and ESAL was higher than would be expected from their areas, supporting the claim that Andalusian waters have an exceptionally diverse molluscan fauna. Thirteen species collected from INDEMARES cruises are here reported for the first time in Spanish waters. The species recorded in Spanish seas represent more than half of the 4340 species of Mollusca recorded within the scope of the European Register of Marine Species, making this the highest species count in European seas. The Canary Islands demarcation holds by far the largest number of endemic species (127), but special mention is needed regarding the $c a .20$ species endemic to the Strait of Gibraltar, a highly anomalous chorotype in the marine realm. The number of non-indigenous species (38) is surprisingly low compared with that of species known in the Mediterranean Sea, amounting to hardly $1.5 \%$ of the total and supporting the view that a high number of native species tends to reduce invasion success. The list is seen as a much needed tool for the identification of priority areas for biodiversity conservation, but requires permanent attention and curating in order to remain up-to-date.
\end{abstract}

Keywords: marine Mollusca; checklist; Spain.

Catálogo nacional de los moluscos marinos de las aguas españolas

Resumen: Se presenta el catálogo actualizado de los moluscos marinos citados en las aguas jurisdiccionales españolas, basado en una exhaustiva revisión bibliográfica y en los hallazgos de campañas recientes. La lista se detalla para las cinco demarcaciones de la Directiva Marco sobre la Estrategia Marina (NOR: costas del norte de España; SUR: costas españolas del golfo de Cádiz, ESAL: estrecho de Gibraltar y mar de Alborán; LEBA: costas del este de España e islas Baleares; CAN: islas Canarias). En la lista se diferencia entre las especies costeras (las que viven desde la zona supralitoral hasta el borde de la plataforma continental), las especies bentónicas o demersales de aguas profundas y las especies holoplanctónicas, y también se indican las especies alóctonas y las que son endémicas para cada una de las demarcaciones. En total, se han citado 2.466 especies de moluscos marinos en aguas españolas, de las cuales 1.126 se conocen sólo en aguas peninsulares y baleares, 498 sólo en aguas canarias, mientras que 842 comparten ambas áreas. Ese número total representa alrededor del $5,5 \%$ de la riqueza específica global de moluscos marinos. Las especies costeras y de la plataforma continental son las más numerosas (1.837), seguidas de las especies de aguas profundas (490) y pelágicas (139), pero la contribución de las especies profundas es especialmente notable en NOR. Están representadas las ocho clases que comprende el filo Mollusca, con una destacable representación de los solenogastros y escafópodos en NOR. La riqueza de especies en SUR y ESAL es superior a la que cabría esperar de sus respectivas áreas, lo que apoya la afirmación de que las costas y aguas andaluzas albergan una malacofauna especialmente diversa. Trece especies recogidas en campañas del proyecto INDEMARES se citan aquí por primera vez en aguas españolas. Las especies registradas en los mares españoles suponen más de la mitad de las 4.340 especies de moluscos registradas en el ámbito geográfico del Registro Europeo de Especies Marinas, lo que supone el mayor número de especies de los países europeos. La demarcación de las islas Canarias es la que contiene con diferencia el mayor número de endemismos (127), pero merecen una mención especial las cerca de 20 especies endémicas del área del estrecho de Gibraltar, un corotipo muy anómalo en el medio marino. El número de especies alóctonas (38) es sorprendentemente bajo si lo comparamos con el número de especies que se consideran introducidas en el mar Mediterráneo, y representa apenas un 
$1,5 \%$ del total, lo que apoya la idea de que un alto número de especies nativas tiende a reducir el éxito de las invasiones. La lista de especies que aquí se presenta constituye una herramienta muy necesaria para la identificación de áreas prioritarias de conservación de la biodiversidad, pero requiere una constante atención y actualización.

Palabras clave: moluscos marinos; catálogo; España.

Citation/Como citar este artículo: Gofas S., Luque A.A., Templado J., Salas C. 2017. A national checklist of marine Mollusca in Spanish waters. Sci. Mar. 81(2): 241-254. doi: http://dx.doi.org/10.3989/scimar.04543.21A

Editor: A. Guerra.

Received: September 2, 2016. Accepted: January 11, 2017. Published: April 4, 2017.

Copyright: (C) 2017 CSIC. This is an open-access article distributed under the terms of the Creative Commons Attribution (CC-by) Spain 3.0 License.

\section{INTRODUCTION}

Mollusca are one of the major animal phyla present in marine environments, making up as much as $25 \%$ of the species in the marine benthos (Appeltans et al. 2012) and usually a large part of the individuals and biomass in any marine assemblage.

There is increasing interest from policy makers in having readily accessible datasets regarding biodiversity, and among these the basic list of species is most essential. The extraordinary variety of geomorphological, oceanographic and biogeographic features of the Spanish seas triggers an extraordinary variety of habitats, which are expected to hold the highest marine biodiversity in Europe (Templado and Pantoja 2009, Templado 2011). However, there are still very few up-to-date checklists of Spanish marine invertebrate taxa and studies on their distribution patterns. Exceptions are the recent compilations of Herrera-Bachiller at al. (2015) and Soler-Membrives and Munilla (2015) on nemerteans and pycnogonids, respectively. Regarding Mollusca, since the publication of Hidalgo (1917) no other monograph has been addressed on the whole Spanish molluscs, although some books have focused on particular regions (i.e. Andalucía, Gofas et al. 2011, Canary Islands, Hernández et al. 2011) or classes of this phylum (Cephalopoda, Guerra 1992; Solenogastres, Caudofoveata and Monoplacophora, GarcíaÁlvarez et al. 2014).

In May 2015, a panel of experts was asked by the Spanish Ministry for Environment (MAGRAMA) to assemble a reference list ('lista patrón') of marine species present in the country's jurisdictional waters, and the authors were responsible for assembling the list of Mollusca. This is a legal commitment for compliance with the requirements of the Marine Strategy Framework Directive (MSFD) of the European Union (EU 2008, Bellas 2014) regarding descriptor 1: Biodiversity. On this occasion we realized that, despite over a century of research, nobody knows exactly how many species are present in Spanish jurisdictional waters.

This initiative is part of the Spanish Inventory of Marine Habitats and Species (Inventario Español de Hábitats y Especies Marinos, IEHEM), the instrument for gathering information on distribution, abundance, condition and use of the natural heritage, with special attention to items that require specific conservation measures or have been declared of community interest. As stipulated in Law 42/2007 on Natural Heritage and Biodiversity (BOE 2007), the Spanish Inventory of Marine Habitats and Species is part of a more inclusive instrument called the Spanish Inventory of Natural Heritage and Biodiversity (Inventario Español del Patrimonio Natural y de la Biodiversidad), implemented through Royal Decree 556/2011 (BOE 2011). The Spanish Inventory of Marine Habitats and Species has two components: an inventory of marine habitats, already published (Templado et al. 2012), and the list of species presently under construction.

The present work stems from this initiative and its main objectives were 1) to provide the first complete review of the species of Mollusca in Spanish waters, including distribution and bathymetric ranges; 2) to analyse numbers of species and sampling intensity across the Iberian Atlantic and Mediterranean regions, and between the Canary Islands and the Iberian Peninsula; 3) to compare the biogeographic patterns of molluscs between the Atlantic and the Mediterranean Sea, and between the Canary Islands and the Iberian Peninsula, with special attention to the occurrence of endemic species; 4) to discuss the role of the Strait of Gibraltar in influencing those patterns; 5) to compare coastal and deep-sea patterns of species distribution; and 6) to assess possible gaps in knowledge of species distribution.

\section{MATERIALS AND METHODS}

\section{Scope}

The scope of the marine checklist includes all Spanish jurisdictional waters, including Canarian and Balearic waters, from the upper shore (supralittoral) to abyssal waters, within the limits of the national EEZ. The "extended continental shelf" in the sense of UNCLOS falls within the scope, but would add to the EEZ an area west of Galicia and the Bay of Biscay where hardly any records would be added.

The Ministry's request was to provide a list of species, detailed according to the five subareas ("demarcations", Fig. 1) established for the purpose of the EU's Marine Strategy Framework Directive (EU 2008) and detailed in the corresponding Spanish Law 41/2010 on the protection of the marine environment (BOE 2010). However, we gathered the basic data according to a more fine-grained subdivision in order to keep track of the relevant sources. The list was handed over in February 2016 but was officially released, without up- 


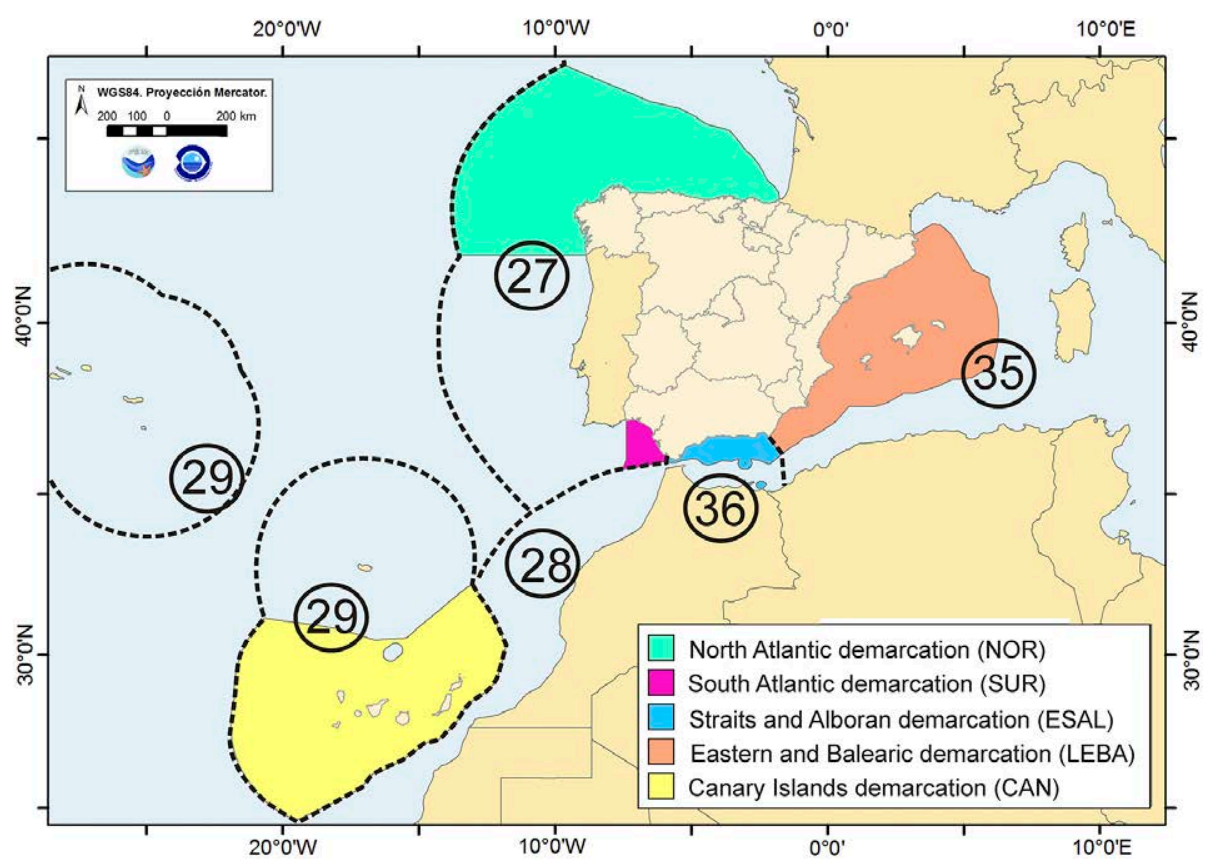

Fig. 1. - The five official demarcations of the Spanish jurisdictional waters for implementation of the Marine Strategy Framework Directive. The dashed contours and circled numbers represent the ecoregions of Spalding et al. 2007 (27, South European Atlantic Shelf; 28, Saharan Upwelling; 29, Azores-Canaries-Madeira; 35, western Mediterranean; 36, Alborán Sea; all except 36 extend further than the mapped area). Background map of Spanish marine demarcations (MSFD DIRECTIVE 2008/56/EC) courtesy of Olvido Tello, Instituto Español de Oceanografía.

dating, only on March 6, 2017 (BOE 2017) and posted on the Ministry's website.

This segregation of data according to subareas is needed because Spanish waters are extremely heterogeneous, spanning a latitudinal gradient from $24.5^{\circ} \mathrm{N}$ to $46.5^{\circ} \mathrm{N}$, including insular as well as mainland coastlines, and comprising parts of the Mediterranean Sea which have extremely specific environmental constraints. The limits of these zones are reasonably compatible with the limits of ecoregions defined in Spalding et al. (2007) (Fig. 1), but the latter encompass the jurisdictional waters of several countries, making their use unpractical in the context of national checklists. For this reason, we entered the records using geographic units (hereafter "geounits", Table 1) defined in the Gazetteer of the Marine Regions website (VLIZ 2016). Distributions of shore and shelf species were entered using coastal geounits, those of deep-sea and pelagic species using marine regions based on the 200 miles EEZ, and species from seamounts using their names (e.g. Galicia Bank, Alborán Ridge).

The Spanish jurisdictional waters are representative of Lusitanian, Mauritanian and Mediterranean regions of Ekman (1953), and entirely comprised in the Lusitanian province, as defined by Briggs (1974) and Briggs and Bowen (2012).

Surfaces of the demarcations are highly unequal: NOR, $306499 \mathrm{~km}^{2}$; SUR, $14978.3 \mathrm{~km}^{2}$; ESAL, 25852.9 $\mathrm{km}^{2}$; LEBA, $232642 \mathrm{~km}^{2}$; and CAN, $486195 \mathrm{~km}^{2}$.

\section{Sources of data}

Molluscs are among the supposedly well-known groups, but the enormous amount of literature in which they are dealt with may well be a source of difficulty for the compilation. We adopted as a standard that every record must be backed by at least one source for every demarcation in which it is reported. We hold the view that there is little use for a raw checklist that merely supplies a list of names without stating a source for each one and without a discussion of the spurious cases. In this respect, the Canarian checklist (Moro et al. 2003) was regarded as useful to bring our attention to names, but frustrating because we then had to track the origin of the records ourselves in order to assess them.

For the purpose of assembling the list, we screened all available published literature sources containing original records of marine Mollusca within the abovementioned scope, including published journal articles and books but also congress communications.

The first range of sources include those which provide lists of records for all the taxa, or at least for a wide range of taxa (Table 1) within a particular geographic unit. Publications in which all species-or at least the most critical species and new records-are illustrated (e.g. Rolán 1983, van Aartsen et al. 1984, Peñas et al. 2006) are first-choice input for the list, because the accuracy of records can be checked. We gave preference to records published after the 1980s, concurring with an enormous drive in Spanish malacology during which much field work was done and many, mostly reliable, faunistic works were published. The internet was extensively used for tracing and retrieving bibliography as well as "grey literature", but websites as such were not used as sources for records.

The second range of sources are taxon-oriented works in which distribution records are provided. These range from comprehensive genus or familylevel revisions covering the whole scope of our list (e.g. Reid 1996, Houart 2001, Verhecken 2007) to sin- 
Table 1. - Geographic units used in establishing the list of marine mollusca in Spanish waters, with mention of the major sources used for each one. Minor sources are listed in WoRMS/MolluscaBase as a source for the distribution records. MRGID refers to the code of the geounits defined in the Marine Regions Gazetteer for the Spanish part of the mentioned areas.

\begin{tabular}{|c|c|c|c|}
\hline Demarcation & Name & MRGID & Major sources of records \\
\hline \multirow[t]{6}{*}{ NOR } & Basque coast & 18018 & Borja and Muxika (2001) \\
\hline & North coast & 14307 & Ortea (1977), Caballer (2006) \\
\hline & Galicia coast & 36276 & Rolán (1983), Rolán et al. (1990), Urgorri et al. (2011) \\
\hline & Bay of Biscay EEZ & 25219 & Locard (1897-1898), Bouchet and Warén $(1980,1985,1986,1993)$, Allen (2008) \\
\hline & NW Atlantic EEZ & 25366 & Locard (1897-1898), Bouchet and Warén (1980, 1985, 1986, 1993), Allen (2008) \\
\hline & Galicia Bank & 2383 & INDEMARES report (unpublished) \\
\hline \multirow[t]{2}{*}{ SUR } & SW coast & 36286 & Gofas et al. (2011) \\
\hline & Gulf of Cádiz EEZ & 2360 & Jeffreys (1878-1885), Locard (1897-1898), INDEMARES report (unpublished) \\
\hline \multirow[t]{7}{*}{ ESAL } & Strait of Gibraltar & 25600 & van Aartsen et al. (1984), Gofas et al. (2011) \\
\hline & Alboran Sea coast & 36287 & Gofas et al. (2011) \\
\hline & Chafarinas Islands & 5363 & Aparici-Seguer and García Carrascosa (1996), Oliver et al. (2015) \\
\hline & Melilla & 36288 & \\
\hline & Alborán Ridge & 3903 & Peñas et al. (2006) \\
\hline & Djibouti Banks & 35852 & Gofas et al. (2014) \\
\hline & Alborán Sea (deep water) & 25604 & Salas (1996), Gofas et al. (2014) \\
\hline \multirow[t]{5}{*}{ LEBA } & East (Levante) coast & 18017 & Oliver Baldoví (2007), Tamayo Goya (2008), Oliver et al. (2012), \\
\hline & Catalonia coast & 14816 & $\begin{array}{l}\text { Giribet and Peñas (1997), Tarruella Ruestes and Fontanet Giner (2001), Peñas and } \\
\text { Giribet (2003), Brunet and Capdevila (2005), Tarruella Ruestes and Lopez Soriano } \\
\text { (2006), Peñas et al. (2008), Capdevila and Folch (2009), Peñas et al. (2009) }\end{array}$ \\
\hline & Balearic coast & 48784 & Dantart et al. (1990) \\
\hline & Balear Sea (deep water) & 3322 & Pons-Moya and Pons (1999) \\
\hline & western Mediterranean EEZ & 25186 & \\
\hline \multirow{2}{*}{ CAN } & Canary Islands & 3743 & $\begin{array}{l}\text { Hernández et al. (2011), Moro-Abad (2015), Ortea et al. (2015), Moro and Ortea } \\
\text { (2015), Moro et al. (2016) }\end{array}$ \\
\hline & Canary Islands EEZ & 8364 & Hernández et al. (2011), Allen (2008) \\
\hline
\end{tabular}

gle records of single species. For taxa for which there is a comprehensive account of the range, this kind of source was preferred over the sum of geounit-oriented records, because the identification is then more likely to be homogeneous across regions.

The main taxon-based sources are listed in Table 2, but overall we took into account hundreds of sources, which will be registered as the basis of the corresponding distribution entries in the World Register of Marine Species (WoRMS Editorial Board 2016) and its component MolluscaBase (MolluscaBase 2016).

Secondary sources were accepted as building blocks for the list and appear as the source for the records entered in WoRMS, if they are aggregators which make explicit statements of the primary sources (e.g. Cervera et al. 2004). General statements of distribution such as "from the British Islands to the Strait of Gibraltar" were disregarded. Care was taken to detect redundant references, where a species is cited by several authors but based on the same original material. This was frequently the case for deep-water species cited by Hidalgo (1917) without reference to Jeffreys (1878-1885) or to Locard (1897-1898), whereas he had no access to additional deep-sea collecting and obviously reported the species on the basis of previously published records.

As a rule we did not incorporate in the list any unpublished records based on personal communications or collection specimens. A notable exception regards species cited in the reports of the INDEMARES "Inventory and designation of the Natura 2000 network in marine areas of the Spanish state" project, a LIFE+ project aimed at documenting by identifying areas of value to the Natura 2000 network in Spanish offshore areas. The project started in 2009 and concluded in 2013 with the proposed designation of these areas as

Table 2. - Some main taxon-oriented sources used in establishing the list. Minor sources are listed in WoRMS/MolluscaBase.

\begin{tabular}{ll}
\hline Taxa & Reference \\
\hline Polyplacophora & Kaas (1985), Kaas and Van Belle (1985-1994), Kaas et al. (2006) \\
Solenogastres, Caudofoveata, Monoplacophora & García-Alvarez et al. (2014) \\
Cephalopoda & Guerra (1992) \\
Scaphopoda & Martínez-Ortí and Cádiz (2012) \\
Cocculinidae, Addisoniidae, Lepetellidae & Dantart and Luque (1994) \\
Scissurellidae, Anatomidae & Geiger (2012) \\
Skeneidae & Rubio et al. (2004) \\
Littorinidae & Reid (1996) \\
Rissoidae & Moolenbeek and Faber (1987), Bouchet and Warén (1993) \\
Cerithiidae & Moreno (1998) \\
Triphoridae & Bouchet (1985, 1997) \\
Epitoniidae (deep water) & Bouchet and Warén (1986) \\
Eulimidae (deep water) & Bouchet and Warén (1986) \\
Muricidae & Houart (2001) \\
Cystiscidae and Marginellidae & Gofas (1989, 1990, 1992), Espinosa et al. (2013, 2014) \\
Cancellariidae & Verhecken (2007) \\
Conoidea (deep water) & Bouchet and Warén (1980) \\
Opisthobranchia & Cervera et al. (2004) and references therein \\
Philinidae & Ohnheiser and Malaquias (2013) \\
Solenidae & von Cosel (1993, 2009)
\end{tabular}


Sites of Community Interest. The authors of the present paper were involved in the reports on Mollusca for three of the ten proposed areas (Galicia Bank, Gulf of Cádiz and Alborán platform) and the new records derived from this source will be detailed hereafter.

\section{Treatment of records and quality control}

Each species is cited according to its current accepted name and higher classification in the World Register of Marine Species (WoRMS Editorial Board 2016) and tied to the internal reference (Aphia ID) of this database in order to facilitate updating. The list was matched against WoRMS using the "Match Taxa" tool therein. In a very few cases (e.g. the generic rearrangement of Tellinidae by Huber et al. 2015) we did not follow the latest taxonomic changes reflected in WoRMS because we found them questionable, lacking the support of a robust phylogenetic hypothesis; in these cases a note is made in the Supplementary Material, Table S1.

According to the instructions we received when assembling the list, records were categorized as "P" (present) or "R" (revisable), without any attempt to take into account abundance.

"Present" is therefore a record which is deemed to be reliable, even if based on only one specimen. The assessment of a record as reliable is drawn from (1) illustrated and checked as correctly identified and/or (2) being consistent with the broader known range of the species and/or (3) whenever possible cross-checked by further independent records.

"Revisable" is applied to published records when there are doubts regarding their validity, yet arguments are insufficient to have them definitively rejected. An "R" status commanded an explanation which could be (1) single records outside the main known range of the species, treated as "occasional", based e.g. on vagrant specimens; (2) possible misidentification of the specimen(s) underlying the record; (3) possibly erroneous locality data of these specimens.

A separate list is given for species once recorded from Spanish waters, but here rejected as such. Pruning the list from unwarranted records was one of the most difficult tasks but also one of the basic reasons why an updated list was needed. Wrong records have explanations similar to the aforementioned (2) and (3) for "R", with definite species misidentifications or definitely wrong locality data, but some of them are merely unsubstantiated i.e. based on a general statement, not on a particular material examined.

Example. Hernández et al. (2011: 340) report Vasconiella jeffreysiana supposedly backed by five references; the first two do not mention the Canaries and the three others are identification guides, giving no detail of occurrences. The illustrated specimen is from Brittany and the record is thus disregarded here. On the next page they report Solecardia rotunda, a species just as small and rare, only found a couple of times after its original description, but the specimen illustrated is from Gran Canaria and matches the original description. This record is uploaded in the list.

Records based on misidentifications were reallocated to the appropriate species if an illustration or a voucher material could allow a correction. Outliers were disregarded unless properly documented.

Example. Enginella bicolor was cited from Tarragona by Capdevila and Folch (2009), without an illustration. This is currently considered as an eastern Mediterranean endemic and the record was disregarded.

A further source of wrong records is the occurrence of fossil or subfossil shells of species which no longer live in the area covered by the list. Shells reworked from Pleistocene or even Cenozoic deposits may look very fresh and their identification and locality data are correct, but they are not an indication that the species is currently living in the area. Some authors (e.g. Giribet and Peñas 1997, Gofas et al. 2014) have made explicit statements that the shells collected belong to quaternary thanatocenosis, but other reports merely list the species name and therefore could provide a basis for a wrong inclusion of a species now extinct in Spanish waters.

Records from borderline localities (e.g. Banyuls on the French Mediterranean coast, St Jean de Luz on the French Basque coast, and Tangiers across the Strait of Gibraltar), were not included if no Spanish records were available, even if their occurrence may be considered as likely. This affects quite a number of species e.g. the Runcina species described by Schmekel and Cappellato $(2001,2002)$.

Old (>50 years) records represent a challenge to the homogeneity of the list. The realization that marine biota have a definite geographical distribution dates back to the mid-19th century, and especially to the pioneering works of MacAndrew $(1851,1852)$ and Forbes (1856). However, at that time the notion that some areas of Europe, and particularly the archipelagos, have a distinctive endemic fauna had not yet emerged, and the literature available for identification was rather limited.

Examples. MacAndrew (1852) reported Rissoa costata [=Manzonia crassa] from the Canaries. Today the genus Manzonia is known to be represented in the Canaries by 12 different species (Moolenbeek and Faber 1987), none of which is Manzonia crassa.

Triphora perversa is a name which agglutinated all European species of the family Triphoridae, and was cited from all five demarcations, until Bouchet and Guillemot (1978) and Bouchet (1985, 1997) demonstrated that the family is represented by some 20 species belonging to 10 genera, and that Monophorus perversus only occurs in LEBA and ESAL.

This means that older records must be taken with caution and sometimes, in view of more recent sources, discarded. Some "forgotten" old records (e.g. the record of Macoma balthica by Hidalgo 1917), if not reinforced in recent papers, were not further taken into account even on the list of rejected species. Discrepancies between recent records and records published long ago may also reflect actual changes in the environment and the biota. Hidalgo (1917) reported Tricolia speciosa from Gibraltar, and this was disregarded by Gofas et al. (2011) because the species has not been found in the last few decades west of Almería, some $200 \mathrm{~km}$ eastwards. However, seagrass habitats in which this species is exclusively found may have been thriving around Gibraltar in the 19th century and Hidalgo's record was not 
necessarily wrong. Shipworms were also common at the time of wooden seafaring vessels and are now scarce, with few species represented in recent listings. We still feel that such records, not synchronous with the bulk of the list, should not be included since the purpose is to provide an account of the current biota. Old records are of less concern in the deep sea. Our knowledge of the Iberian offshore fauna still relies heavily on early expeditions such as those of the Porcupine (1870) and Travailleur and Talisman (1880-1883) and the heart of things is not likely to have changed substantially since this collecting effort was made.

\section{Information to be included - Attributes}

\section{Depth range and environmental compartments}

The list differentiates (1) coastal species, living from the supralittoral to the shelf break, (2) deep-sea benthic or demersal species, and (3) holoplanktonic species, including borers of driftwood and nektonic cephalopods. For discrimination between deep-sea and coastal species, we adjusted to the threshold retained by the World Register of Deep-Sea Species (Glover et al. 2016) of having at least part of their records below $500 \mathrm{~m}$. This leaves, together with the shelf species, a small number of borderline species which have no such records. This is a relatively simple division but was also adjusted to the recommendations of Costello et al. (2015: 11).

\section{Non-indigenous species}

Regarding areas of origin, we distinguish native and alien (introduced) species. In this context we include locally introduced species e.g. rated as native in the Mediterranean coast and introduced on the Atlantic coast, or native elsewhere in the Mediterranean and introduced to a Spanish coast.

In the official list handed over to the Ministry, all non-indigenous species were to be treated as " $R$ ", the non-indigenous attribute being an additional reason for " $R$ " status. We do not endorse this approach and here we apply for non-indigenous species the same criteria as for native species (rated "P" if established and definitely present, or " $\mathrm{R}$ " if they meet the above criteria for "R" status), and separately make a statement that they are non-indigenous (as "PI" or "RI" in the list).

All the species here recorded as non-indigenous are given a distribution entry in the World Register of Introduced Marine Species (Pagad et al. 2016), a specialized portal viewing the WoRMS database with emphasis on introduced distribution.

\section{Endemic species}

Endemic is here understood in the strict acceptation of biogeography, i.e. the relation of a taxon to its area. Therefore, we scored as endemic to a particular demarcation any species not occurring anywhere else, worldwide, than in the demarcation involved. For the global count we scored as endemic to Spanish waters any species not occurring elsewhere, but possibly occurring in more than one demarcation. Exceptions are made for species endemic to the Strait of Gibraltar and also occurring on the Moroccan shore of the Strait and/ or in Gibraltar harbour (scored as endemic to the ESAL demarcation), and species occurring both in the Canaries and in Selvagens Islands (scored as endemic to the CAN demarcation).

\section{Data analysis}

A presence-absence matrix including only the shore and shelf species was constructed in order to analyse the affinity between the species composition of the fauna in the five demarcations. For this purpose we calculated a Bray-Curtis similarity index using Primer 6 software (Clarke and Warwick 1994).

\section{RESULTS}

\section{Species numbers}

A total of 2466 marine Mollusca have been reported from Spanish waters, of which 1126 are recorded only from waters surrounding the Iberian Peninsula and the Balearic Islands, 498 are recorded from the Canaries with no peninsular records, and 842 are shared. The detail of records according to the demarcations is given in Table 3 (see also Supplementary Material, Table S1). Only 284 species, hardly more than $10 \%$ of the total, are recorded in all five demarcations. Conversely, more than half are found only in one or two demarcations (1067 species in 1 demarcation, 455 species in 2 demarcations, 340 species in 3 demarcations and 320 species in 4 demarcations). Shore and shelf species are the most numerous (1837 species), followed by deepsea benthic species (490) and pelagic species (139) (Table 4), but the contribution of the deep-sea species is most noteworthy in NOR (one-third of the species, compared with 10\%-20\% elsewhere). The above numbers all refer to the sum of "P" + "R" records.

All eight molluscan classes were represented (Table 5), with numbers globally reflecting their worldwide importance. However, the numbers of solenogastres

Table 3. - Number of molluscan species recorded in Spanish jurisdictional waters, by demarcation and status. The total of endemic species is slightly more than the sum because some species are found in several demarcations, yet endemic to Spanish waters as a whole. The total of globally rebutted records is less than the sum of demarcations, because locally rebutted records may be accepted in other demarcations.

\begin{tabular}{|c|c|c|c|c|c|c|}
\hline & NOR & SUR & ESAL & LEBA & CAN & Total \\
\hline Accepted records & 1053 & 766 & 1245 & 1165 & 1262 & 2371 \\
\hline Revisable records & 47 & 8 & 44 & 31 & 78 & 95 \\
\hline Rebutted records & 49 & 5 & 27 & 21 & 139 & 114 \\
\hline Non-indigenous & 22 & 7 & 4 & 12 & 6 & 38 \\
\hline Endemic to the geounit & 20 & 1 & 40 & 5 & 127 & 204 \\
\hline
\end{tabular}


Table 4. - Number of molluscan species recorded in Spanish jurisdictional waters, per demarcation and biome. First number, "P" records, number in brackets, "R" records.

\begin{tabular}{lcccccc}
\hline & NOR & SUR & ESAL & LEBA & CAN & Total \\
\hline Coastal & $663(28)$ & $627(4)$ & $1077(33)$ & $1003(26)$ & $971(65)$ & $1772(65)$ \\
Deep-Sea & $319(17)$ & $103(4)$ & $114(10)$ & $97(3)$ & $185(10)$ & $463(27)$ \\
Pelagic & $71(2)$ & 36 & $54(1)$ & $65(2)$ & $106(3)$ & $136(3)$ \\
Pelagic (non-Cephalopod) & 24 & 16 & $35(1)$ & $39(1)$ & $51(1)$ & 66 \\
\hline
\end{tabular}

Table 5. - Number of benthic molluscan species recorded in Spanish jurisdictional waters, per class. First number, "P" records; number in brackets, " $\mathrm{R}$ " records.

\begin{tabular}{|c|c|c|c|c|c|c|}
\hline & NOR & SUR & ESAL & LEBA & $\mathrm{CAN}$ & Total \\
\hline Monoplacophora & 2 & - & - & - & - & 2 \\
\hline Caudofoveata & 10 & 1 & 7 & 7 & - & 13 \\
\hline Solenogastres & $24(1)$ & 4 & 5 & $8(1)$ & 3 & $33(2)$ \\
\hline Polyplacophora & $17(6)$ & $10(1)$ & $17(3)$ & $15(1)$ & 18 & $37(8)$ \\
\hline Gastropoda & $619(28)$ & $464(6)$ & $898(40)$ & $819(22)$ & $935(61)$ & $1710(66)$ \\
\hline Bivalvia & $279(7)$ & 234(1) & $268(1)$ & $246(5)$ & $220(15)$ & $437(14)$ \\
\hline Scaphopoda & $24(1)$ & 9 & 9 & 15 & 14 & $31(1)$ \\
\hline Cephalopoda & $78(4)$ & 44 & 41 & $55(2)$ & $72(2)$ & $109(4)$ \\
\hline Total & $1053(47)$ & $766(8)$ & $1245(44)$ & $1165(31)$ & $1262(78)$ & $2371(95)$ \\
\hline
\end{tabular}

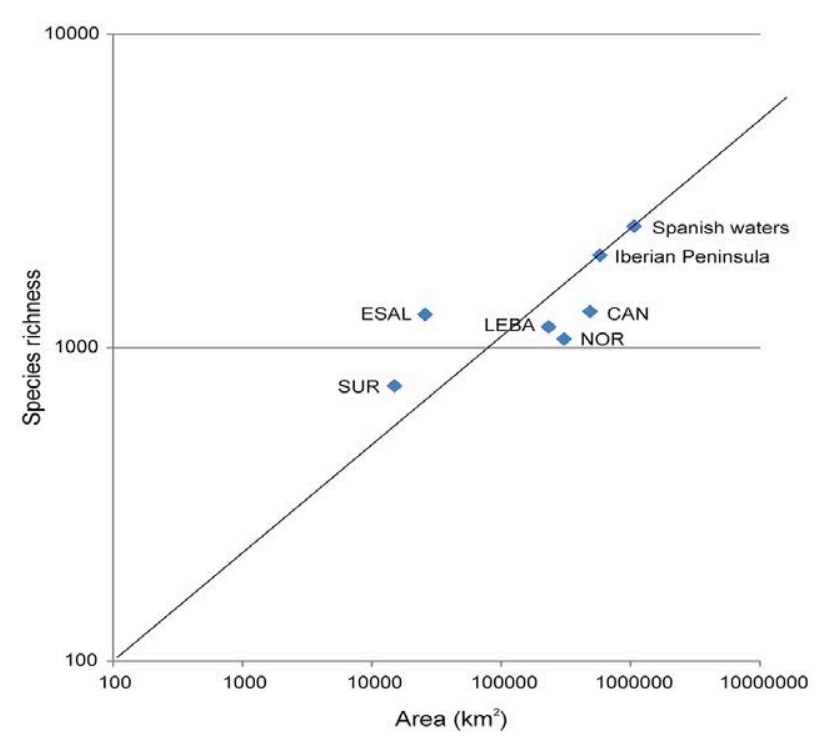

Fig. 2. - Species-area plot for the five demarcations, the total of the four Iberian demarcations, and the total of Spanish waters.

and scaphopods are notably higher in NOR than in any other demarcation, due to the outstanding representation of these two groups on the Galicia Bank. Bivalves represent nearly half of the species in SUR, where soft bottoms are prevalent.

A plot of number of species versus the surface of the demarcations on a logarithmic scale (Fig. 2) shows that species richness in SUR and ESAL is higher than would be expected in their areas, supporting the claim (Gofas et al. 2011) that Andalusian waters have an exceptionally diverse molluscan fauna. The two Mediterranean demarcations are by far those which have most species in common (Fig. 3).

\section{New records}

Data from the INDEMARES unpublished reports contribute to the list a total of 13 species which are recorded for the first time from Spanish waters, and 37 further species which are first recorded from at least

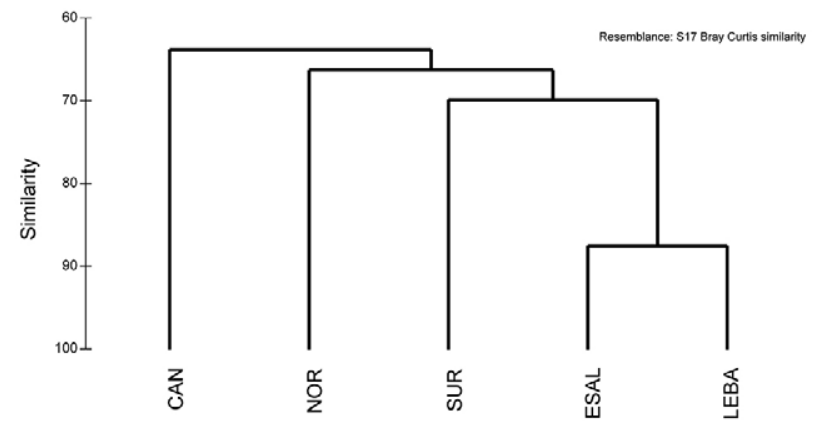

Fig. 3. - Similarity in species composition between the five demarcations, based on Bray-Curtis index.

one of the demarcations. These new records are given in Table 6. Some of them are already included in the published monographs of the INDEMARES areas; others will be detailed in forthcoming papers on the malacological fauna of Galicia Bank and of Gulf of Cádiz.

\section{Progress of knowledge}

A survey of the progress of this inventory in the last few decades (Fig. 4) indicates that the discovery of new species shows no sign of inflexion. In comparison, virtually none of the species known to Hidalgo (1917) would have been described in the preceding decade (Fig. 5). At

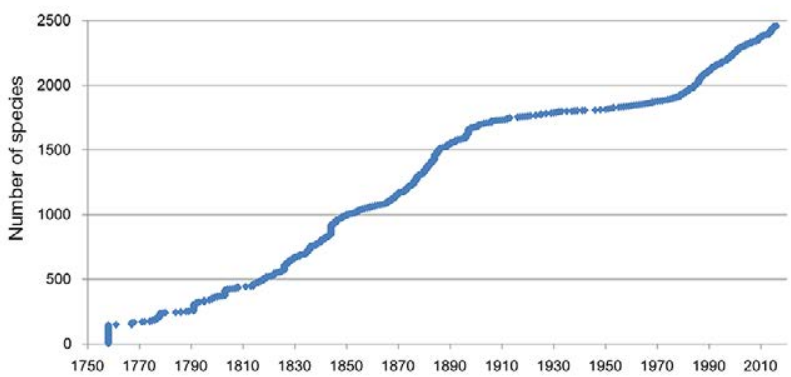

Fig. 4. - Cumulative number of species ("Present" and "Revisable") present in Spanish waters, plotted against their year of first description. Note the steeper slope in the late 19th century and from 1980 to the present, and the low rate of new descriptions in the first $3 / 4$ of the 20th century. 
Table 6. - New records of molluscan species from the ECOMARG programme, the INDEMARES AVILÉS, INDEMARES CHICA and INDEMARES BANGAL reports.

\begin{tabular}{|c|c|c|c|}
\hline Species & Aphia ID & New records & Previous records \\
\hline Leptochiton rarinotus (Jeffreys, 1883) & 385826 & NOR/ECOMARG & New to Spain \\
\hline Connexochiton platynomenus Kaas, 1979 & 140134 & NOR/BANGAL & CAN \\
\hline Placiphorella atlantica (Verrill and Smith, 1882) & 140387 & NOR/BANGAL & CAN \\
\hline Propilidium exiguum (W. Thompson, 1844) & 140188 & SUR/CHICA & NOR, ESAL, LEBA, CAN \\
\hline Anatoma tenuis (Jeffreys, 1877) & 532385 & NOR/BANGAL & $\mathrm{CAN}$ \\
\hline Cerithiopsis atalaya Watson, 1885 & 139073 & SUR/CHICA & ESAL, CAN \\
\hline Onchodia valeriae (Giusti Fr., 1987) & 139098 & SUR/CHICA & ESAL, CAN \\
\hline Epitonium dallianum (Verrill and S. Smith, 1880) & 139720 & SUR/CHICA (“R”) & NOR \\
\hline Epitonium pseudonanum Bouchet and Warén, 1986 & 139730 & SUR/CHICA & ESAL, CAN \\
\hline Opaliopsis atlantis (Clench and Turner, 1952) & 139753 & SUR/CHICA & ESAL, CAN \\
\hline Costaclis mizon (Watson, 1881) & 139784 & NOR/BANGAL & CAN \\
\hline Fuscapex cabiochi Bouchet and Warén, 1986 & 139813 & NOR/BANGAL & New to Spain \\
\hline Curveulima devians (Monterosato, 1884) & 152380 & SUR/CHICA & ESAL, LEBA \\
\hline Teinostoma azoricum (Dautzenberg and H. Fischer, 1896) & 138703 & NOR/BANGAL & New to Spain \\
\hline Haloceras cingulata (Verrill, 1884) & 140061 & NOR/BANGAL & New to Spain \\
\hline Pseudosimnia flava Fehse, 2003 & 225844 & SUR/CHICA & New to Spain \\
\hline Tectonatica rizzae (Philippi, 1844) & 140554 & SUR/CHICA & NOR, ESAL, LEBA, CAN \\
\hline Boreotrophon dabneyi (Dautzenberg, 1889) & 181036 & NOR/BANGAL & New to Spain \\
\hline Pagodula echinata (Kiener, 1840) & 181040 & SUR/CHICA & NOR, ESAL, LEBA, CAN \\
\hline Buccinum humphreysianum Bennet, 1824 & 138865 & SUR/CHICA & NOR, ESAL, LEBA \\
\hline Chauvetia balgimae Gofas and Oliver, 2010 & 488191 & SUR/CHICA & New to Spain \\
\hline Nassarius coralligenus (Pallary, 1900) & 140493 & SUR/CHICA & ESAL \\
\hline Amphissa acutecostata (Philippi, 1844) & 139190 & SUR/CHICA & NOR, ESAL, LEBA, CAN \\
\hline Anachis aliceae (Pallary, 1900) & 139191 & SUR/CHICA & ESAL \\
\hline Mitrella pallaryi (Dautzenberg, 1927) & 139204 & SUR/CHICA & NOR, ESAL, CAN \\
\hline Gibberula turgidula (Locard and Caziot, 1900) & 139513 & SUR/CHICA & ESAL, LEBA \\
\hline Brocchinia clenchi Petit, 1986 & 138972 & NOR/BANGAL (“R”) & SUR ("R") \\
\hline Spirotropis confusa (Seguenza, 1880) & 573431 & NOR/AVILÉS, SUR/CHICA & ESAL \\
\hline Spirotropis monterosatoi (Locard, 1897) & 139663 & SUR/CHICA & ESAL, CAN \\
\hline Drilliola emendata (Monterosato, 1872) & 139234 & SUR/CHICA & ESAL, LEBA \\
\hline Drilliola loprestiana (Calcara, 1841) & 183133 & SUR/CHICA & NOR, ESAL, LEBA, CAN \\
\hline Pleurotomella gibbera Bouchet and Warén, 1980 & 139348 & SUR/CHICA & ESAL, CAN \\
\hline Taranis moerchii (Malm, 1861) & 139384 & SUR/CHICA & NOR, ESAL, LEBA ("R"), CAN \\
\hline Teretia teres (Reeve, 1844) & 139385 & SUR/CHICA & NOR, ESAL, LEBA, CAN \\
\hline Dacrydium hyalinum (Monterosato, 1875 ) & 140446 & SUR/CHICA & ESAL \\
\hline Parvamussium propinquum (E. A. Smith, 1885) & 181288 & NOR/BANGAL & CAN \\
\hline Pseudamussium clavatum (Poli, 1795) & 140716 & SUR/CHICA & NOR, ESAL, LEBA \\
\hline Spondylus gussonii O. G. Costa, 1830 & 141550 & SUR/CHICA & NOR, ESAL \\
\hline Lima marioni Fischer, 1882 & 140234 & SUR/CHICA & NOR \\
\hline Acesta excavata (Fabricius, 1779) & 140232 & NOR/AVILÉS & CAN \\
\hline Limatula laminifera (E. A. Smith, 1885) & 140240 & NOR/BANGAL & New to Spain \\
\hline Thyasira granulosa (Monterosato, 1874) & 141664 & SUR/CHICA & ESAL, LEBA, CAN ("R") \\
\hline Syssitomya pourtalesiana Oliver, 2012 & 597707 & NOR/BANGAL & New to Spain \\
\hline Halicardia flexuosa Verrill and S. Smith, 1881 & 156779 & NOR/BANGAL & New to Spain \\
\hline Lyonsiella abyssicola (Sars G. O., 1872) & 141947 & NOR/BANGAL & CAN \\
\hline Policordia atlantica Allen and Turner, 1974 & 405955 & NOR/BANGAL & New to Spain \\
\hline Cuspidaria circinata (Jeffreys, 1876) & 139441 & SUR/CHICA & NOR \\
\hline Myonera angularis (Jeffreys, 1876) & 139460 & NOR/BANGAL & New to Spain \\
\hline Rhinoclama inflata (Jeffreys, 1882) & 505153 & NOR/BANGAL & $\mathrm{CAN}$ \\
\hline Protocuspidaria colpodes (Dautzenberg and H. Fischer, 1897) & 139466 & NOR/BANGAL & New to Spain \\
\hline Bathoxiphus ensiculus (Jeffreys, 1877) & 139690 & NOR/BANGAL & CAN \\
\hline
\end{tabular}

that time, less than half of the species currently known from the Iberian Peninsula and the Balearic Islands had been recorded (see details in Supplementary Material, Table S1). The state of knowledge was even worse for the Canary Islands, where only 170 species had been recorded at the time of Odhner (1932).

\section{Non-indigenous species}

Only 38 non-indigenous species (3 Polyplacophora, 23 Gastropoda, 12 Bivalvia) are found in the list. Of these, 36 are here rated as established (3 Polyplacophora, 22 Gastropoda, 11 Bivalvia), marked as "PI" in Supplementary Material, unlike in the official list, where all NIS would be scored "R". Two of them are very ancient introductions and were not understood as such until the 20th century. These are the polyplacophoran Chaetopleura angulata, described again as Chiton lusi- tanicus by Tilesius (1802), who did not know its South American origin, and Crassostrea angulata, believed to be a Portuguese endemic at the time of its description and now known to originate from Taiwan (Batista et al. 2005). These are here rated as established, marked as "PI" in Supplementary Material. Some of the established species, e.g. Bostrycapulus odites in Alicante harbour (Collin et al. 2010) and Marginella glabella in Malaga harbour (Luque et al. 2012) have been persisting for years or decades without spreading out of their original entry site. Six species are translocations within European waters, from the Spanish Mediterranean coast to Galicia (Bolinus brandaris, Hexaplex trunculus and Fusinus rostratus), from the Adriatic to Spanish waters (Gibbula albida and Gibbula adriatica), or from mainland Spain to the Canaries (Phorcus richardi and Littorina saxatilis). Only two NIS species (the sea hare Bursatella leachii and the cockle Fulvia fragilis, 


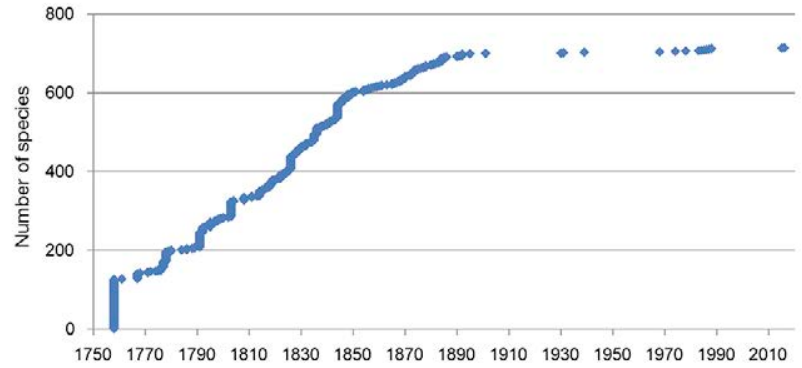

Fig. 5. - Cumulative number of species ("Present" and "Revisable") present in Spanish waters of the Iberian Peninsula and the Balearic Islands, and known to Hidalgo (1917), plotted against their year of first description. This represents less than half of the 1976 species currently recorded. Some of the species were cited by Hidalgo with names now regarded as wrong, and were reassigned to species described later, or are now denoted under another name because the name then in usage is preoccupied or otherwise invalid. These are Nucula nitidosa, Nucula hanleyi, Emarginula octaviana, Parvioris ibizenca, Ringicula gianninii, Strobiligera brychia, Skeneopsis sultanarum, Manzonia vigoensis, Parvicardium vroomi, Emarginula christiaensi, Brocchinia clenchi, Odostomia carrozzai, Bela menkhorsti, Parviturbo ergasticus and Dendropoma lebeche.

Tamayo Goya 2008, González-Wangüemert et al. 2014) in Spanish waters are clearly of Red Sea origin and actually qualify as the most hardy Lessepsian species in their progression westwards.

\section{DISCUSSION}

\section{Comparison with other areas}

The species recorded in Spanish seas represent more than half of the 4340 species of Mollusca recorded in the scope of the European Register of Marine Species (ERMS), spanning from the Arctic seas to the Canary Islands and the Azores, and the Mediterranean and Black Sea. Also, those 2466 species represents around $5.5 \%$ of the global marine molluscan richness, estimated at between 43600 and 46000 species (according to Rosenberg 2014 and Bouchet et al. 2016, respectively). Most of the missing European species are either boreal species, which meet their southern limit in Scandinavia or the British Isles, or eastern Mediterranean species (including many Lessepsian non-indigenous species). A smaller number of missing species are known from the Atlantic coast of Morocco but are recorded neither from the southern Iberian Peninsula nor from the Canaries.
This is the highest species number among European countries (Table 7). The contribution of the Canaries is noteworthy, but the net increase to the total based on the Canaries contributes 498 species (not only endemics, but species not recorded from Iberian waters) and the Iberian-only inventory would still retain the leadership with 1968 species.

The Italian list of 1995 (Minelli 1996) included a total of 2141 species of molluscs, but these included 592 non-marine gastropods (3 Neritidae, 44 Architaenioglossa, 2 Melanopsidae, 2 Pomatiasidae, 68 freshwater Hydrobioidea, 2 Bythiniidae, 4 Valvatidae, 32 Basommatophora, 435 Stylommatophora) and 20 Bivalvia (3 Unionoida, 1 Dreissenidae, 17 Sphaeriidae) which brings the count of marine species down to 1529 . Fourteen endemic species were reported, mostly in the family Rissoidae. Twenty years later, these numbers increased to 1602 in the revised checklist assembled by the Italian Society of Marine Biology (SIBM) (Relini 2008).

There are no detailed published estimates for France (not taking into account overseas provinces and territories). Following legal commitments similar to those reported for Spain, the French Ministry in charge of environment commissioned the Muséum National d'Histoire Naturelle with setting up the "Inventaire National du Patrimoine Naturel" (INPN), which is an online list of 1279 marine species (1255 native, 24 non-indigenous or cryptogenic) with the details indicated in Table 7. It is explicitly reported that none are considered endemic. Some deep-sea species are included, but obviously the bulk of species reported (e.g. Bouchet and Warén 1980, 1985, 1986, 1993) from deep water in the Bay of Biscay are missing. Therefore, final numbers for the French Atlantic coast may well approach the Iberian ones; assuming that the deep-sea species from the Bay of Biscay contribute some 300400 species, as in the Spanish NOR demarcation, the total number for France may be of the order of 16001700 species. Other European countries are not likely to reach higher numbers. The Turkish list (Öztürk et al. 2014), possibly the most updated and carefully assembled in the Mediterranean, holds 1065 species, of which more than 100 are Lessepsian.

One of the best known molluscan faunas in the World is that surrounding the British Isles. The most recent list (Seaward 1990) includes 746 numbered species entries (of which 21 are marked as deleted) referring to a previously published Atlas, and 252 un-

Table 7. - Number of species representing each Class of the Mollusca in several European and Mediterranean countries. The numbers in bracket are those of species reported as non-indigenous.

\begin{tabular}{|c|c|c|c|c|c|c|c|}
\hline & $\begin{array}{c}\text { Spain } \\
(\mathrm{P}+\mathrm{R}, \text { this } \\
\text { work })\end{array}$ & $\begin{array}{c}\text { Fauna Italia } \\
\text { (1995) (Minelli } \\
\text { 1996) }\end{array}$ & $\begin{array}{c}\text { Fauna Italia } \\
\text { (SIBM 2006) } \\
\text { (Relini 2008) }\end{array}$ & $\begin{array}{l}\text { France } \\
\text { (INPM } \\
\text { website) }\end{array}$ & $\begin{array}{c}\text { British list } \\
\text { (Seaward } \\
\text { 1990) }\end{array}$ & $\begin{array}{c}\text { Turkey } \\
\text { (Öztürk et al. } \\
\text { 2014) }\end{array}$ & $\begin{array}{l}\text { Mediterranean } \\
\text { (Coll et al. } \\
\text { 2010, Zenetos } \\
\text { et al. 2010) }\end{array}$ \\
\hline Monoplacophora & 2 & 1 & 1 & - & - & - & 1 \\
\hline Caudofoveata & 13 & 4 & 6 & 2 & 6 & 2 & 9 \\
\hline Solenogastres & 35 & 12 & 16 & 8 & 14 & 1 & 29 \\
\hline Polyplacophora & $45(3)$ & 24 & 29 & 18 & 18 & 17 & $31(2)$ \\
\hline Gastropoda & $1776(24)$ & 1100 & $1151(12)$ & $880(10)$ & $601(4)$ & $706(77)$ & $1564(139)$ \\
\hline Bivalvia & $451(11)$ & 317 & $329(12)$ & $303(14)$ & $276(4)$ & 279 (39) & $400(68)$ \\
\hline Scaphopoda & 32 & 13 & 13 & 20 & 24 & 10 & 14 \\
\hline Cephalopoda & 113 & 58 & $57(4)$ & 48 & 35 & $50(2)$ & $65(6)$ \\
\hline TOTAL & $2466(38)$ & 1529 & $1602(28)$ & $1279(24)$ & $974(8)$ & $1065(118)$ & $2113(215)$ \\
\hline
\end{tabular}


numbered additions, mostly deep-water species. This brings to a total of 977 species.

\section{Endemism}

A number of species listed as endemic to one of the demarcations are actually rare species, known so far only from their type locality but liable to be found in other areas. There are nevertheless a small number of species which seem to qualify as endemic to some of the Iberian demarcations. A few possibly endemic species were described recently from Galicia (e.g. the rissoids Onoba breogani and O. galaica, Rolán 2008) and the Balearic Islands (e.g. the rissoid Alvania balearica Oliver and Templado 2009).

A special comment is needed regarding the species endemic to the Strait of Gibraltar, a highly anomalous chorotype in the marine realm. They are not Spanish endemics strictly speaking, as they occur (or have occurred prior to anthropic impact) along the Moroccan shore of the Straits and around Gibraltar, but their occurrence abroad spans less than ten kilometres from the border, and therefore we feel that those species still qualify as short-range endemics and as vulnerable species. Of the 40 species listed as endemic to ESAL, about 20 (Gofas 1998) are endemic to the Strait of Gibraltar. The area surrounding Alboran Island also supports a small number of endemic species (e.g. Trophonopsis alboranensis, Jujubinus alboranensis), which are probably actual endemics, and other ESAL endemics are found both in the Straits and around Alboran Island (e.g. Tricolia deschampsi).

The Canary Islands demarcation holds by far the largest number of endemic species (127), among which are four species of Jujubinus (family Trochidae), 22 species of Rissoidae, 25 species of Marginellidae and 12 species of Runcinidae. More than half of these endemics were described in the 21 st century and only six prior to 1979 , which means not only that the discovery of these species is recent, but also that they have only recently been given taxonomic recognition. Canarian endemic species are mostly gastropods with direct development and therefore with a poor ability for dispersal, and only three are bivalves. Most of them are shallow water species; there are seven deep-sea species known only from their Canarian type localities, but these possibly have a more extensive range.

It is noteworthy that none of the short-range endemics present in Spanish marine waters are included in national or international legal texts. This is due in part to the fact that their description and the realization that they are of concern is more recent than most legal texts listing protected species. Therefore, an urgent task for the scientific community is to document the actual area of occupancy of those species, to demonstrate that they comply with the expected status for protected species, and to initiate the process for their inclusion.

\section{Non-indigenous species in Spanish waters}

The number of non-indigenous species in Spanish marine waters is surprisingly low. It is probably under- estimated in the Canary Islands, where species reported from both the islands and the neighbouring West African coast may (1) have a natural range spanning both areas, (2) be exclusive to the mainland coast but have records from the Canaries based on displaced or mislabelled material, (3) have been actually introduced to the Canaries (especially when Canarian fishing boats were operating on Saharan coasts) without becoming established, or (4) be actual aliens established there. It is generally very difficult to distinguish which of these situations applies, since there is a long tradition of operating on mainland fishing grounds and other events, such as importation of sand from the mainland coast for beach refurbishing, have given countless opportunities for introduction. Situation (1) can only be proven when Pleistocene fossils document pre-human occurrences of the species, and introductions can be proven only if the source area is remote (e.g. the small Australian muricid Bedeva paivae).

Only four species (Bostrycapulus odites, Marginella glabella, Godiva quadricolor, Bedeva paivae) are presumed to have secured their first European foothold in Spain, whereas most have been recorded previously in other parts of the Mediterranean or are native to them.

The overall occurrence of non-indigenous mollusc species in Spanish waters amounts to hardly $1.5 \%$ of the total, despite definite exposure to vectors such as shipping and aquaculture. This finding supports the view that a high number of native species tends to reduce invasion success (Stachowicz et al. 1999).

\section{How accurate are these numbers?}

An exact reckoning of species numbers in the country's jurisdictional waters is not seen as possible. Uncertainty is unavoidable and may be taxonomic, resulting from contrasting opinions regarding synonymy/ splitting of taxa, distributional depending on the accuracy of the records, or merely the result of omissions in the assembly of the list. A rough estimate of the uncertainty may be taken from the numbers of species rated as "revisable" which represent about $4 \%$ of the total. A further number of species are rated as "present" on the basis of the criteria retained for inclusion, but subjectively would not be fully trusted.

The Canary Islands fauna is where the uncertainty on final numbers is most striking. The CAN demarcation holds the highest number of revisable records (78 species) and of rebutted records (139 species, more than $10 \%$ of the total), which is the legacy of some publications (e.g. Nordsieck and García Talavera 1979) with poor illustrations, poor taxonomy and poor control on the origin of the specimens. The BIOTA team (Moro et al. 2003) has made commendable efforts to prune the list from old, unsupported records, but more scrutiny is still needed. On the other hand, most of the deep sea surrounding the Canaries is hardly explored and will certainly yield more species.

\section{Gaps in knowledge}

The knowledge of the demarcations is highly unequal. Whereas the Alboran Sea and Galicia can match 
the level of coverage of the British Isles, to the point that a new record is not easily added, other areas are still more or less inaccurately known.

The SUR demarcation claims the lowest number of species, and this may in part be explained by genuine physical characteristics of the area. The demarcation is notably smaller than the others (Fig. 1), the coastline is mostly sandy, with scant occurrence of rocky substrate, and is consequently inhospitable for many species. In the deeper area, the path of the Mediterranean Outflow Water has been documented (Salas 1996) as having a depleted fauna and lacking many species found at comparable depth off Morocco. However, much of this apparent poverty is due to the lack of recent collecting followed by appropriate sorting of the material, and the actual number should be expected to be in excess of 1000 , as in the other demarcations. The ongoing study of the INDEMARES CHICA Marine Protected Area may provide a step forward in this direction.

Another considerably underscored area is that surrounding the Balearic Islands. Although this is not apparent in our figures because the Balearic Islands belong together with the eastern Iberian mainland in the LEBA demarcation, most of the records underlying the 1165 reported species are from the mainland. As mentioned above, there may be species endemic to the Balearic Islands, and some species may reach these islands and not the Iberian mainland (e.g. the marginellid Volvarina mitrella, see Gofas 1989).

Although reasonably well explored, particularly regarding opisthobranchs, the North Iberian coast lacks recent, reliable faunal records backed with illustrations. The catalogue of Borja and Muxica (2001) contains several spurious entries (e.g. Pinna nobilis, probably a confusion with juveniles of Atrina fragilis) and is not illustrated.

Regarding environmental compartments, the littoral fauna is of course better known than the deep-sea fauna, but the lack of knowledge of the latter is higher in some areas. The Bay of Biscay, Galicia Bank, Ibero-Moroccan Gulf and Alboran Sea have been the target of several deep-sea explorations. The French campaigns BIOGAS and SEAMOUNT, the INDEMARES projects in Le Danois Bank, Galicia Bank and Gulf of Cádiz, and the BALGIM expedition (1986) on either side of the Strait of Gibraltar have provided reasonable insights on the deep-sea fauna of those areas. The same cannot be said of the Balearic Islands area, which is hardly explored at all and only presumed to be species-poor like the rest of the Mediterranean (Bouchet and Taviani 1989), and of the deep waters surrounding the Canaries, which are probably the most promising frontier in the knowledge of marine fauna in Spanish jurisdictional waters.

More surprising is the scant knowledge of planktonic species. This is of importance since many pelagic species are likely to find their distributional limits around the Iberian Peninsula; for example, we could not document positive records of the pteropod Limacina retroversa, and were therefore unable to determine whether the species still lives in Iberian waters or the abundant shells of this species found in sediments are remains from a past climatic cold spell, as they probably are.

\section{Identifying end users}

Completing an up-to-date checklist of the fauna in a country's territory is an important requirement as a tool for management. The checklist allows a simple but robust analysis of species richness in the country, gives visibility to the presence of endemic species and is needed to organize and plan projects dealing with mapping of the distributional data and to identify priority areas for biodiversity conservation (Stoch 2000).

Another aspect regards ecological or impact studies, which commonly record species that are not properly identified and/or do not belong to the local fauna. The detailed checklist allows some quality control by crosschecking such works against the recorded occurrences.

Our perception is that it is unacceptable that, after over two centuries of research, the answer to the question "how many marine molluscs (or any other group) are there in Spanish waters?" was "nobody knows exactly". We still cannot give final figures in which every species would be assessed as present or absent, but have set the basis for progressing towards this goal. During the year that has elapsed between the submission of the initial list to the Ministry and the final acceptance of the present manuscript, updates due to new findings and new taxonomic opinions amounted to 15 new entries, the deletion of 12 entries newly reported as unsupported, changes in the detail of records for over 100 existing entries and changes in the generic allocation of over 50 more. These figures show that more than $5 \%$ of the list may change in less than a year and that this is a dynamic database which must be curated by taxonomic experts so as to remain up-to-date.

\section{SUPPLEMENTARY MATERIAL}

A complete list of the species is presented as a large table in Supplementary Material, arranged in taxonomic order, with the detail of occurrences. The last sheet is the list of species globally rejected as part of the Spanish fauna; locally rejected species are marked as such in the main list.

The Aphia ID column refers to the internal number attributed to the species in the World Register of Marine Species and its components ERMS, MolluscaBase and Introduced Species. The supraspecific classification in columns is given according to WoRMS.

For each demarcation (NOR, North Atlantic demarcation; SUR, South Atlantic demarcation; ESAL, Straits and Alboran demarcation; LEBA, Eastern and Balearic demarcation; CAN, Canary Islands demarcation), three separate columns provide a count of "Present", "Revisable" and "Rejected" records, and a fourth column provides the status of the species expressed as "P" (Present), "PE" (Present, endemic to this demarcation), "PI" (Present, introduced in this demarcation regardless of whether it is native somewhere else in Spain), "R" (Revisable), "RI" (Revisable, introduced) or "F" (rejected in the particular demarcation). For CAN, an additional column indicates the status of the species in the BIOTA checklist (Moro et al. 2003): NPR, probably native (the default status for most mol- 
luscan species); NSE, definitely native (mostly associated with the endemic species); dud, stated as dubious.

Further columns indicate the total number of demarcations in which the species occurs ("P" + "R"), with an additional column (only " $R$ ") indicating species which have no ascertained record in Spanish waters. ENDEM. and INTROD. indicate the species which are endemic or introduced.

The column "Hidalgo" indicates the demarcations (1, NOR; 2, SUR; 3, ESAL; 4, LEBA; 5, CAN) in which the particular species was known at the time of Hidalgo (1917) or, for the Canary Islands, at the time of Odhner (1932); numbers in red indicate rejected records.

Five columns indicate intertidal species (Shore), shore and shelf species (Shelf), deep-sea benthic species occurring deeper than $500 \mathrm{~m}$ (Bathyal) and pelagic and holoplanktonic or nektonic species (Pelagic).

A final column of Remarks is mainly devoted to the grounds for rejection. Literature cited therein is not always included in the bibliography of this paper but is always included in the World Register of Marine Species (WoRMS).

\section{ACKNOWLEDGEMENTS}

We thank Ángel Guerra, Victoriano Urgorri, Óscar García-Álvarez, José Lucas Cervera, Alejandro Escánez, Alejandro de Vera, Fátima Hernández, Leopoldo Moro and Rodrigo Riera, experts in different molluscan groups, who provided valuable information and input for the compilation of the present checklist. Thanks are also due to Alberto Serrano and Víctor Díaz del Río (Instituto Español de Oceanografía, IEO), leaders of the Galicia Bank and Gulf of Cádiz Chimneys workpackages of the project LIFE+ INDEMARES, respectively, for the invitation to participate in the BANGAL 0711 (2011, AL and SG) and CHICA 0211 (2011, SG) cruises and for handing over the molluscan material for study; to shipboard companions and crew of R/V Miguel Oliver (BANGAL 0711) and R/V Cornide de Saavedra (CHICA 0211) for efficient and pleasant collaboration during these cruises. We are also grateful to Blanca Ruiz Franco, Ainhoa Pérez Puyol and Antonio Fernández y García de Vinuesa (MAGRAMA), who commissioned us to compile the checklist of molluscs within the framework of the Spanish Inventory of Marine Habitats and Species, and to Olvido Tello (IEO) for allowing us to use the map of Spanish marine demarcations.

\section{REFERENCES}

Allen J.A. 2008. Bivalvia of the deep Atlantic. Malacologia 50: $57-173$

https://doi.org/10.4002/0076-2997-50.1.57

Aparici-Seguer V., García-Carrascosa A.M. 1996. Moluscos de los fondos de sustratos blandos de las islas Chafarinas (Mar de Alborán, Mediterráneo). Datos preliminares. Iberus 14: 85-91.

Appeltans W., Ahyong S.T., Anderson G., et al. 2012. The magnitude of global marine species diversity. Curr. Biol. 22: 2189-2202.

https://doi.org/10.1016/j.cub.2012.09.036

Batista F., Leitão A., Huvet A, et al. 2005. The taxonomic status and origin of the Portuguese oyster Crassostrea angulata (Lamarck, 1819). In: Proceedings, 1st International Oyster Symposium,
Tokyo, Japan, July 13-14. Oyster Research Institute News, 18: $6 \mathrm{pp}$. unpaginated.

Bellas J. 2014. The implementation of the Marine Strategy Framework Directive: Shortcomings and limitations from the Spanish point of view. Mar. Policy 50: 10-17. https://doi.org/10.1016/j.marpol.2014.05.004

BOE. 2007. Ley 42/2007, de 13 de diciembre, del Patrimonio Natural y de la Biodiversidad. Boletín Oficial del Estado, 299, 14 December 2007: 51275-51327.

BOE. 2010. Ley de Protección del Medio Marino. Boletín Oficial del Estado, 317, 30 December 2010: 108464-108488.

BOE. 2011. Real Decreto 556/2011, de 20 de abril, para el desarrollo del Inventario Español del Patrimonio Natural y la Biodiversidad. Boletín Oficial del Estado, 112, 11 May 2011, Sec. I: 47905-47932.

BOE. 2017. Resolución de 17 de febrero de 2017, de la Secretaría de Estado de Medio Ambiente, por la que se establecen tres listas patrón: la de las especies terrestres, la de las especies marinas y la de los hábitats terrestres, presentes en España. Boletín Oficial del Estado, 55, 6 March 2017, Sec. III: 16648-16649.

Borja A., Muxika I. 2001. Actualización del catálogo de los moluscos marinos de la costa vasca, en campañas realizadas por AZTI. Iberus 19: 67-85.

Bouchet P. 1985. Les Triphoridae de Méditerranée et du proche Atlantique (Mollusca, Gastropoda). Lavori SIM 21: 5-58.

Bouchet P. 1997. Nouvelles observations sur la systématique des Triphoridae de Méditerranée et du proche Atlantique. Boll. Malacol. 31: 205-220.

Bouchet P., Guillemot H. 1978. The Triphora perversa-complex in Western Europe. J. Moll. Stud. 44: 344-356.

Bouchet P., Taviani M. 1989. Atlantic deep sea gastropods in the Mediterranean: new findings. Boll. Malacol. 25: 137-148.

Bouchet P. Warén A. 1980. Revision of the North-East Atlantic bathyal and abyssal Turridae (Mollusca: Gastropoda). J. Moll. Stud. 46 Suppl. 8: 1-119. https://doi.org/10.1093/mollus/46.Supplement 8.1

Bouchet P., Warén A. 1985. Revision of the Northeast Atlantic bathyal and abyssal Neogastropoda excluding Turridae (Mollusca, Gastropoda). Boll. Malacol. Suppl. 1: 121-296.

Bouchet P., Warén A. 1986. Revision of the Northeast Atlantic bathyal and abyssal Aclididae, Eulimidae, Epitonidae (Mollusca, Gastropoda). Boll. Malacol. Suppl. 2: 297-576.

Bouchet P., Warén A. 1993. Revision of the Northeast Atlantic bathyal and abyssal Mesogastropoda. Boll. Malacol. Suppl. 3: 579-840.

Bouchet P., Bary S., Héros V., et al. 2016. How many species of molluscs are there in the world's oceans, and who is going to describe them? In: Héros V., Strong E., Bouchet P. (eds), Tropical Deep-Sea Benthos 29. Muséum national d'Histoire naturelle, Paris. Mém. Mus. Natl. Hist. Nat. 208: 9-24.

Briggs J.C. 1974. Marine zoogeography. McGraw-Hill, New York. $475 \mathrm{pp}$.

Briggs J.C., Bowen B.W. 2012. A realignment of marine biogeographic provinces with particular reference to fish distributions. J. Biogeogr. 39: 12-30. https://doi.org/10.1111/j.1365-2699.2011.02613.x

Brunet J., Capdevila M. 2005. Atlas malacològic del delta de l'Ebre. Privately published, $198 \mathrm{pp}$

Caballer M. 2006. Catálogo de los sacoglosos y opistobranquios (Mollusca: Gastropoda) de sustrato rocoso de la bahía de Santander. Revisión de los géneros con especies crípticas. Santander. PhD. thesis, Univ. Cantabria, 500 pp.

Capdevila M., Folch J. 2009. Fauna malacològica del Parc Subaquàtic de Tarragona (el Tarragonès, Catalunya, Espanya). Spira 3: 33-51

Cervera J.L., Calado G., Gavaia C., et al. 2004. An annotated and updated checklist of the opisthobranchs (Mollusca: Gastropoda) from Spain and Portugal (including islands and archipelagos). Bol. Inst. Esp. Oceanogr. 20: 1-122 pp.

Clarke K.R., Warwick R.M. 1994. Change in marine communities: an approach to statistical analysis and interpretation. Plymouth Marine Laboratory, Plymouth, $859 \mathrm{pp}$.

Coll M., Piroddi C., Steenbeek J., et al. 2010. The biodiversity of the Mediterranean Sea: estimates, patterns, and threats. Plos One 5: e11842 http://dx.doi.org/10.1371/journal.pone.0011842

Collin R., Ramos-Esplá A.A., Izquierdo A. 2010. Identification of the South Atlantic spiny slipper limpet Bostrycapulus odites Collin, 2005 (Caenogastropoda: Calyptraeidae) on the Spanish Mediterranean coast. Aquat. Invasions 5: 197-200. 
https://doi.org/10.3391/ai.2010.5.2.11

Costello M.J., Claus S., Dekeyzer S., et al. 2015. Biological and ecological traits of marine species. PeerJ 3: e1201. https://doi.org/10.7717/peerj.1201

Dantart L., Luque A.A. 1994. Cocculiniformia and Lepetidae (Gastropoda: Archaeogastropoda) from Iberian waters. J. Moll. Stud. 60: 277-313. https://doi.org/10.1093/mollus/60.3.277

Dantart L., Frechilla M., Ballesteros M. 1990. Fauna malacológica del Estany del Peix (Formentera). Iberus 9: 111-125.

Ekman S. 1953. Zoogeography of the sea. Sidgwick and Jackson, London, $417 \mathrm{pp}$.

Espinosa J., Ortea J., Moro L. 2013. Descripción de nuevas especies de marginelas (Mollusca: Neogastropoda: Marginellidae) de las islas Canarias, con aclaraciones sobre otros taxones citados previamente. Vieraea 41: 21-34.

Espinosa J., Ortea J., Pérez-Dionis G., et al. 2014. Adiciones a la familia Marginellidae (Mollusca: Neogastropoda) en las islas Canarias y Mauritania. Vieraea 42: 19-34.

EU. 2008. Directive 2008/56/EC of the European Parliament and of the Council of 17 June 2008 establishing a framework for community action in the field of marine environmental policy (Marine Strategy Framework Directive). Official Journal of the European Union, L 164: 19-40.

Forbes E. 1856. Map of the distribution of marine life, illustrated chiefly by fishes, Molluscs \& Radiata; showing also the extent and limits of the Homoiozoic belts. In: Johnston A.K. The Physical Atlas of Natural phenomena, second and enlarged edition. William Blackwood and Sons, Edimburgh and London [posthumous publication], pl. 31.

García-Álvarez Ó., Salvini-Plawen L.V., Urgorri V., et al. 2014. Mollusca. Solenogastres, Caudofoveata, Monoplacophora. Fauna Ibérica 38. Museo Nacional de Ciencias Naturales, CSIC, Madrid, 295 pp.

Geiger D.L. 2012. Monograph of the little slit shells. Volume 1. Introduction, Scissurellidae. pp. 1-728. Volume 2. Anatomidae, Larocheidae, Depressizonidae, Sutilizonidae, Temnocinclidae, pp. 729-1291. Santa Barbara Museum of Natural History Monographs, 7.

Giribet G., Peñas A. 1997. Fauna malacológica del litoral del Garraf. Iberus 15: 41-93.

Glover A.G., Higgs N., Horton T. 2016. World Register of DeepSea species. Accessed on 2016-06-18 at http://www.marinespecies.org/deepsea

Gofas S. 1989. Le genre Volvarina (Marginellidae) dans la Méditerranée et l'Atlantique du Nord-Est. Boll. Malacol. 25: 159-182.

Gofas S. 1990. Le genre Gibberula (Marginellidae) en Méditerranée. Lavori SIM 23: 113-139

Gofas S. 1992. Le genre Granulina (Marginellidae) en Méditerranée et dans l'Atlantique oriental. Boll. Malacol. 28: 1-26.

Gofas S. 1998. Marine molluscs with a very restricted range in the Strait of Gibraltar. Divers. Distrib. 4: 255-266.

Gofas S., Moreno D., Salas C. 2011. Moluscos marinos de Andalucía. 2 volumes. Servicio de Publicaciones e intercambio científico, Univ. Málaga, i-xvi, 798 pp.

Gofas S., Salas C., Rueda J.L., et al. 2014. Mollusca from a speciesrich deep-water Leptometra community in the Alboran Sea. Sci. Mar. 78: 537-553. https://doi.org/10.3989/scimar.04097.27A

González-Wangüemert M., Domínguez-Godino J., Giménez-Casalduero F., et al. 2014. Genetic signature of a recent invasion: The ragged sea hare Bursatella leachii in Mar Menor (SE Spain). Biochem. Sys. Ecol. 54: 123-129. https://doi.org/10.1016/j.bse.2014.01.008

Guerra A. 1992. Moluscos Cefalópodos. Fauna Ibérica, vol. 1. Museo Nacional de Ciencias Naturales, CSIC, Madrid, 327 pp., 12 láms.

Hernández J.M., Rolán E., Swinnen F., et al. 2011. Moluscos y conchas marinas de Canarias. ConchBooks, Hackenheim, 716 pp.

Herrera-Bachiller A, Fernández-Álvarez F.A., Junoy J. 2015. A Taxonomic Catalogue of the Nemerteans (Phylum Nemertea) of Spain and Portugal. Zool. Sci. 32: 507-522. https://doi.org/10.2108/zs140242

Hidalgo J.G. 1917. Fauna Malacologica de España, Portugal y las Baleares. Trab. Mus. Nac. Cienc, Nat., Zoologia 30: 1-752.

Houart R. 2001. A review of the Recent Mediterranean and Northeastern Atlantic species of Muricidae. Evolver, Roma, $227 \mathrm{pp}$.

Huber M., Langleit A., Kreipl K. 2015. Tellinidae. In: Huber M., Compendium of bivalves 2. ConchBooks, Harxheim, 907 pp.

Jeffreys J.G. 1878-1885. On the Mollusca procured during the H. M. S. "Lightning" and "Porcupine" expedition. Proc. Zool.
Soc. London, Part 1 (1878): 393-416, pls 22-23; Part 2 (1879): 553-588 pl. 45-46 [October 1879]; Part 3 (1881): 693-724, pl. 61; Part 4 (1881): 922-952, pls 70-71 [1882]; Part 5 (1882): 656-687, pls 49-50 [1883]. Part 6 (1883): 88-115 pls 19-20; Part 7 (1884): 111-149, pls 9-10; Part 8 (1884): 341-372, pls 26-28; Part 9 (1885): 27-63, pls 4-6.

Kaas P. 1985. The genus Acanthochitona Gray, 1821 (Mollusca, Polyplacophora) in the north-eastern Atlantic Ocean and in the Mediterranean Sea, with designation of neotypes of $A$. fascicularis (L. 1767) and of A. crinita (Pennant, 1777). Bull. Mus. Nat. His. Nat. (sec. A Zool.) (4)7(3): 579-603.

Kaas P., Van Belle R.A. 1985-1994. Monograph of living Chitons (Mollusca: Polyplacophora). Vol. 1 [1985]. Order Neoloricata: Lepidopleurina, 244 pp. Vol. 2 [1985]. Suborder Ischnochitonina. Ischnochitonidae: Schizoplacinae, Callochitoninae Lepidochitoninae, 198 pp. Vol. 3 [1987]: Suborder Ischnochitonina. Ischnochitonidae: Chaetopleurinae, and Ischnochitonidae (pars). Additions to Vols 1 and 2, 302 pp. Vol. 4 [1990]. Suborder Ischnochitonina. Ischnochitonidae: Ischnochitoninae (continued). Additions to Vols 1, 2 and 3, 298 p. Vol. 5 [1994]. Suborder Ischnochitonina. Ischnochitonidae: Ischnochitoninae (concluded), Callistoplacinae; Mopaliidae. Additions to Volumes 1-4, 402 pp. E. J. Brill/W. Backhuys, Leiden.

Kaas P., Van Belle R.A., Strack H. 2006. Monograph of living chitons (Mollusca: Polyplacophora); volume 6: Suborder Ischnochitonina (concluded); Schizochitonidae and Chitonidae, additions to volumes 1-5, E.J. Brill, Leiden, 464 pp.

Locard A. 1897-1898. Expéditions scientifiques du Travailleur et du Talisman pendant les années 1880, 1881, 1882 et 1883 . Mollusques testacés. Paris, Masson. vol. 1 [1897], p. 1-516 pl. 1-22; vol. 2 [1898], p. 1-515, pl. 1-18

Luque A.A., Barrajón A., Remón J.M., et al. 2012. Marginella glabella (Mollusca: Gastropoda: Marginellidae): a new alien species from tropical West Africa established in southern Mediterranean Spain through a new introduction pathway. Mar. Biod. Rec. 5: e17. https://doi.org/10.1017/S1755267212000012

MacAndrew R. 1851. Notes on the distribution and range in depth of Mollusca and other marine animals observed on the coast of Spain, Portugal, Barbary, Malta, and Southern Italy in 1849. Report of the 20th meeting of the British Association for the Advancement of Science, pp. 264-304.

MacAndrew R. 1852. Note on the Mollusca observed during a short visit to the Canary and Madeira Islands \& c., in the months of April and May 1852. Ann. Mag. Nat. Hist. Ser. 2, 10: 100-108. https://doi.org/10.1080/03745485609495658

Martínez-Ortí A., Cádiz L. 2012. Living scaphopods from the Valencian coast (E Spain) and description of Antalis caprottii $\mathrm{n}$. sp. (Dentaliidae). Animal Biod. Cons. 35: 71-94.

Minelli A. 1996. La checklist delle specie della fauna italiana. Un bilancio del progetto. Bollettino del Museo Civico di Storia naturale di Verona 20: 249-261. Online version http://www faunaitalia.it/checklist/

MolluscaBase. 2016. Accessed at http://www.molluscabase.org.

Moolenbeek R.G., Faber M.J. 1987. The Macaronesian species of the genus Manzonia (Gastropoda: Rissoidae). Part I. De Kreukel 23(1): 1-16, pl. 1.; Part II. De Kreukel 23 (2-3): 23-31; Part III. De Kreukel 23: 166-179, pl. 2-3.

Moreno D. 1998. Sistemática y biología del género Bittium (Gastropoda, Prosobranchia) en la Península Ibérica. $\mathrm{PhD}$. thesis, Univ. Complutense, Madrid, 473 pp.

Moro-Abad L. 2015. Moluscos opistobranquios bentónicos de las islas Canarias y su entorno. PhD thesis, Univ. La Laguna, 448 pp.

Moro L., Ortea J. 2015. Nuevos taxones de babosas marinas de las islas Canarias y de Cabo Verde (Mollusca: Heterobranchia). Viearea 43: 21-86

Moro L., Ortea J., Bacallado J.J. 2016. Nuevas citas y nuevos datos anatómicos de las babosas marinas (Mollusca: Heterobranchia) de las islas Canarias y su entorno. Rev. Acad. Canar. Cienc. 28: $9-52$.

Moro L., Martín J.L., Garrido M.J., et al. (eds). 2003. Lista de especies marinas de Canarias (algas, hongos, plantas y animales). Consejería de Política Territorial y Medio Ambiente del Gobierno de Canarias, 248 pp.

Nordsieck F., García-Talavera F. 1979. Moluscos Marinos de Canarias y Madera (Gastropoda). Aula de Cultura, Tenerife, 208 pp., 46 pls.

Odhner N.H. 1932. Beitrage zur Malakozoologie der Kanarischen Inseln. Lamellibranchien, Cephalopoden, Gastropoden. Ark. Zool. 23A: 1-116. 
Ohnheiser L.T., Malaquias M. 2013. Systematic revision of the gastropod family Philinidae (Mollusca: Cephalaspidea) in the north-east Atlantic Ocean with emphasis on the Scandinavian Peninsula. Zool. J. Linnean Soc. 167: 273-326. https://doi.org/10.1111/zoj.12000

Oliver Baldoví J.D. 2007. Catálogo de los Gasterópodos testáceos marinos de la parte Sur del Golfo de Valencia (España). Iberus 25: $29-61$.

Oliver J.D., Templado J. 2009. Dos nuevas especies del género Alvania (Caenogastropoda, Rissoidae). Iberus 27: 57-66.

Oliver J.D., Templado J., Kersting D. 2012. Gasterópodos marinos de las islas Columbretes (Mediterráneo occidental). Iberus 30: 49-87.

Oliver J.D., Calvo M., Guallart J., et al. 2015. Gasterópodos marinos de las islas Chafarinas (Mediterráneo suroccidental). Iberus 33: $97-150$.

Ortea J.A. 1977. Moluscos marinos Gasterópodos y Bivalvos del litoral asturiano entre Ribadesella y Ribadeo con especial atención a la subclase de los Opistobranquios. Ph.D. thesis, Univ. Oviedo, $580 \mathrm{pp}$.

Ortea J., Moro L., Bacallado J.J. 2015. Babosas marinas canarias. Turquesa Ediciones, Islas Canarias, 133 pp.

Öztürk B., Doğan A., Bitlis-Bakir B., et al. 2014. Marine molluscs of the Turkish coasts: an updated checklist. Turk. J. Zool. 38: 832-879. https://doi.org/10.3906/zoo-1405-78

Pagad S., Hayes K., Katsanevakis S. et al. 2016. World Register of Introduced Marine Species (WRIMS). Accessed on 2016-06-18 at http://www.marinespecies.org/introduced

Peñas A., Giribet G. 2003. Adiciones a la fauna malacológica del Garraf. Iberus 21: 177-189.

Peñas A., Rolán E., Luque A.A., et al. 2006. Moluscos marinos de la isla de Alborán. Iberus 24: 23-151.

Peñas A., Rolán E., Ballesteros M. 2008. Segunda adición a la fauna malacológica del litoral del Garraf (NE de la Península Ibérica). Iberus 26: 15-42

Peñas A., Rolán E., Almera J. 2009. Fauna malacológica de un fondo detrítico fangoso en El Maresme, Barcelona (nordeste de la Península Ibérica). Iberus 27: 19-56.

Pons-Moya J., Pons G.X. 1999. Noves dades sobre mol-luscs de profunditat del SW de Mallorca (Illes Balears, Mediterrania Occidental). Boll. Soci. Hist. Nat. Balears 42: 39-46.

Reid D.G. 1996. Systematics and evolution of Littorina. The Ray Society, London, $\mathrm{x}+463 \mathrm{pp}$.

Relini G. (ed.) 2008. Checklist della flora e della fauna dei mari italiani. I Parte. Biol. Mar. Medit. 15(s1): 1-38.

Rolán E. 1983. Moluscos de la ría de Vigo 1. Gasterópodos. Thalassas, Anexo 1: 1-383.

Rolán E. 2008. The genus Onoba (Mollusca, Caenogastropoda, Rissoidae) from NW Spain, with the description of two new species. Zoosymposia 1: 233-245. https://doi.org/10.11646/zoosymposia.1.1.13

Rolán E., Otero Schmitt J., Rolán-Âlvarez E. 1990. Moluscos de la ría de Vigo 2. Poliplacóforos, Bivalvos, Escafópodos, Cefalópodos. Thalassas, Anexo 2: 1-276.

Rosenberg G. 2014. A new critical estimate of named species-level diversity of the recent Mollusca. Amer. Malac. Bull. 32: 308-322. https://doi.org/10.4003/006.032.0204

Rubio F., Dantart L., Luque A. 2004. El género Dikoleps (Gastropoda, Skeneidae) en las costas ibéricas. Iberus 22: 113-132.

Salas C. 1996. Marine Bivalves from off the Southern Iberian Peninsula collected by the Balgim and Fauna 1 expeditions. Haliotis 25: 33-100

Schmekel L., Cappellato D. 2001. Contributions to the Runcinidae. 1. Six new species of the genus Runcina (Opisthobranchia Cephalaspidea) in the Mediterranean. Vie Milieu 51: 141-160.

Schmekel L., Cappellato D. 2002. Contributions to the Runcinidae. II. Three new species and comparative studies on five established species of Runcina (Opisthobranchia Cephalaspidea) in the Mediterranean. Vie Milieu 52: 86-102.

Seaward D.R. 1990. Distribution of the marine molluses of north west Europe. Nature Conservancy Council, Peterborough, UK. $114 \mathrm{pp}$

Soler-Membrives A., Munilla T. 2015. PYCNOIB: Biodiver- sity and Biogeography of Iberian Pycnogonids. PLoS ONE 10: e0120818.

https://doi.org/10.1371/journal.pone.0120818

Spalding M.D., Fox H.E., Allen G.R., et al. 2007. Marine ecoregions of the world: A bioregionalization of coastal and shelf areas. BioScience 57: 573-583. https://doi.org/10.1641/B570707

Stachowicz J.J., Whitlatch R.B., Osman R.W. 1999. Species diversity and invasion resistance in a marine ecosystem. Science 286: 1577-1579.

https://doi.org/10.1126/science.286.5444.1577

Stoch F. 2000. How many endemic species? Species richness assessment and conservation priorities in Italy. Belg. J. Entomol. 2: $125-133$

Tamayo Goya J.C. 2008. Catálogo de los bivalvos marinos del sector central del golfo de Valencia (España). Iberus 26: 69-80.

Tarruella Ruestes A., Fontanet Giner M. 2001. Moluscos marinos del Golf de Sant Jordi (L'Ampolla) y del Port dels Alfacs. Spira 1: 1-5.

Tarruella Ruestes A., Lopez Soriano J. 2006. Moluscos marinos del Baix Camp (Tarragona, NE Península Ibérica). Spira 2: 1-16.

Templado J. 2011. La diversidad marina en España. In: Viejo J.L. (ed). Biodiversidad: aproximación a la diversidad botánica y zoológica en España. Mem. R. Soc. Esp. Hist. Nat. (2a época), 9: 343-362

Templado J., Pantoja J. 2009. Un medio marino del que estar orgulloso (por ahora). Documentación Administrativa, número extraordinario sobre biodiversidad, Instituto Nacional de Administración Pública, Madrid, pp. 171-193.

Templado J., Ballesteros E., Galparsoro I., et al. 2012. Inventario español de hábitats y especies marinos. Guía interpretativa: Inventario español de hábitats marinos. Ministerio de Agricultura, Alimentación y Medio Ambiente, Madrid, 229 pp. Available online at http://www.mapama.gob.es/es/costas/temas/proteccion-medio-marino/GUIA_INTERP_HABITATS_WEB_tcm7270736.pdf

Tilesius W.A. 1802. Beschreibumg einer neuen Chiton species ausdem Tagus, Chiton lusitanicus. Jahrb. Naturgesch.: 213-221, pl. 6.

Urgorri V., Díaz-Agras G., Besteiro C., et al. 2011. Additions to the inventory of Mollusca Opistobranchia of Galicia (NW Iberian Peninsula). Thalassas 27: 77-100.

van Aartsen J.J., Menkhorst H.P.M.G., Gittenberger E. 1984. The marine Mollusca of the Bay of Algeciras, Spain, with general notes on Mitrella and Turridae. Basteria, Supplement 2: 1-135.

Verhecken A. 2007. Revision of the Cancellariidae (Mollusca, Neogastropoda, Cancellarioidea) of the eastern Atlantic $\left(40^{\circ} \mathrm{N}\right.$ $40^{\circ} \mathrm{S}$ ) and the Mediterranean. Zoosystema 29: 281-364.

VLIZ. 2016. Intersect of IHO Sea Areas and Exclusive Economic Zones (version 1). Available online at http://www.marineregions.org/

von Cosel R. 1993. The razor shells of the eastern Atlantic. Part 1: Solenidae and Pharidae I (Bivalvia: Solenacea). Arch. Molluskenkd. 122 (Zilch Festschrift): 207-321.

von Cosel R. 2009. The razor shells of the eastern Atlantic, part 2. Pharidae II: the genus Ensis Schumacher, 1817 (Bivalvia, Solenoidea). Basteria 73: 9-56.

WoRMS Editorial Board. 2016. World Register of Marine Species. Accessed 2016-06-18. Available at http://www.marinespecies.org

Zenetos A., Gofas S., Verlaque M., et al. 2010. Alien species in the Mediterranean Sea by 2010. A contribution to the application of European Union's Marine Strategy Framework Directive (MSFD). Part I. Spatial distribution. Mediterr. Mar. Sci. 11: 381-493.

https://doi.org/10.12681/mms.87

\section{SUPPLEMENTARY MATERIAL}

The following supplementary material is available through the online version of this article and at the following link:

http://scimar.icm.csic.es/scimar/supplm/sm04543esm.xlsx

Table S1. - Complete list of the marine Mollusca species from Spanish waters arranged in taxonomic order, with the detail of occurrences. 